\title{
The addition of jaboticaba skin flour to muffins alters the physicochemical composition and their sensory acceptability by children
}

\author{
Adição de farinha da casca de jabuticaba altera a composição físico-química e a \\ aceitabilidade sensorial de muffin entre crianças
}

\begin{abstract}
Jéssica Micheletti ${ }^{1}$, Jaqueline Machado Soares ${ }^{1}$, Bruna Callegari Franco ${ }^{2}$, Izabella Renatta Almeida de Carvalho ${ }^{2}$, Camila Jordão Candido², Elisvânia Freitas dos Santos², Daiana Novello1*

1 Universidade Estadual do Centro-Oeste (UNICENTRO), Departamento de Nutrição, Setor de Ciências da Saúde, Guarapuava/PR - Brasil

2 Universidade Federal de Mato Grosso do Sul (UFMS), Faculdade de Ciências Farmacêuticas, Alimentos e Nutrição (FACFAN), Campo Grande/MS - Brasil
\end{abstract}

\section{*Corresponding Author}

Daiana Novello, Universidade Estadual do Centro-Oeste (UNICENTRO), Departamento de Nutrição, Setor de Ciências da Saúde, Rua Simeão Camargo Varela de Sá, 3, Vila Carli, CEP: 85040-080, Guarapuava/PR - Brasil, e-mail: nutridai@gmail.com

Cite as: The addition of jaboticaba skin flour to muffins alters the physicochemical composition and their sensory acceptability by children. Braz. J. Food Technol., v. 21, e2017089, 2018.

Received: June 16, 2017; Accepted: Dec. 12, 2017

\section{Abstract}

This work aimed to evaluate the sensory acceptance by children of muffins containing different levels of jaboticaba skin flour. It also aimed to determine the physicochemical composition of the traditional product and compare it with that containing the highest level of jaboticaba skin flour showing acceptance similar to that of the traditional muffin. Five muffin formulations containing different levels of jaboticaba skin flour were prepared: $0 \%$ (standard), $4.5 \%, 9 \%, 13.5 \%$ and $18 \%$. A group of 65 untrained tasters of both genders, aged from 7 to 10, took part in the sensory evaluation. The moisture, ash, protein, lipid, carbohydrate, calorie and dietary fibre levels were evaluated. The samples presented no significant alterations $(p>0.05)$ for the attributes of appearance, aroma and colour. The formulations containing $0 \%$ and $4.5 \%$, received the highest scores $(p<0.05)$ for flavour, texture and overall acceptance as compared to those with $13.5 \%$ and $18 \%$ jaboticaba skin flour. The sample with $9 \%$ was the one with the highest level of jaboticaba skin flour with acceptance similar to that of the traditional muffins. Higher moisture, ash and dietary fibre levels and lower lipid and protein levels were detected in the formulation with $9 \%$, when compared to the traditional muffins, but there were no significant changes in the carbohydrate and calorie contents. It was concluded that a level of up to $9 \%$ jaboticaba skin flour in the muffins was well accepted by the child tasters, achieving a sensory acceptance similar to that of the traditional product and with good commercial potential.

Keywords: Childhood; Food waste; Fruits; Nutrition; Reuse; Subproducts.

\section{Resumo}

Este trabalho teve como objetivo avaliar a aceitabilidade sensorial de muffin adicionado de diferentes níveis de farinha da casca de jabuticaba, entre crianças. Além disso, determinar a composição físico-química do produto tradicional e daquele com maior teor de farinha de casca de jabuticaba e com aceitação semelhante ao tradicional. Foram elaboradas cinco formulações de muffin: 0\% (padrão), 4,5\%, 9\%, 13,5\% e 18\% de farinha de casca de jabuticaba. Participaram da avaliação sensorial 65 avaliadores não treinados, de ambos os gêneros, com idade entre 7 e 10 anos. Foram avaliados os teores de umidade, cinzas, proteína, lipídio, carboidrato, calorias e fibra alimentar. As amostras não diferiram significativamente $(p>0,05)$ para os atributos de aparência, aroma e cor. Sabor, textura, aceitação global e intenção de compra tiveram maiores notas $(p<0,05)$ para as formulações com $0 \%$ e $4,5 \%$, comparadas àquelas com $13,5 \%$ e $18 \%$ de farinha de casca de jabuticaba. A amostra com $9 \%$ foi aquela com maior teor de farinha de casca de jabuticaba e com aceitação semelhante ao muffin tradicional. Maiores teores de umidade, cinzas e fibra alimentar, e 
menores teores de lipídios e proteínas foram constatados para a formulação com 9\%, quando comparada com a formulação padrão. Não houve diferença significativa para os conteúdos de carboidrato e calorias. Conclui-se que um nível de adição de até 9\% de farinha da casca de jabuticaba em muffin foi bem aceito pelos avaliadores infantis, obtendo-se aceitação sensorial semelhante ao produto padrão, com bom potencial de comercialização.

Palavras-chave: Infância; Desperdício de alimentos; Frutas; Nutrição; Reaproveitamento; Subprodutos.

\section{Introduction}

Food waste occurs in different ways throughout the production chain, and the harvesting, processing, distribution and consumption phases are those mainly responsible for the waste. A high level of waste $(25 \%)$ results from food processing when the skins, seeds and stalks are discarded (GUSTAVSSON et al., 2011; GALANAKIS, 2016). It has been estimated that 1.3 billion tons of food annually go to waste worldwide, $45 \%$ being from fruits and vegetables (GUSTAVSSON et al., 2011).

The use of byproducts for the development of new products represents an important strategy for the food industry, since it can improve the nutritional and market values of the products and, at the same time, cooperate with the reduction in environmental waste (AYALA-ZAVALA et al., 2011). The skins, seeds and stalks can be transformed into flour to be added to preparations as ingredients (FERREIRA et al., 2015), and hence one can increase their stability and shelf-life, as well the sensory and functional attributes. The use of byproducts allow expanding the variety of products destined for human consumption, thus reducing costs (AYALA-ZAVALA et al., 2011). Some studies have shown the feasibility of substituting wheat flour with fruit skin flours (from melon, jaboticaba and banana, amongst others) in several products (cakes, cookies and bread). The results suggested good sensory acceptance and market potential (AL-SAYED; AHMED, 2013; ZAGO et al., 2015; ESHAK, 2016).

The jaboticaba is a fruit originating in the southeastern and central regions of Brazil. It belongs to the Myrciaria species and has a round shape and dark red skin. The tree is a native of subtropical climates but can adapt well to tropical climates and can therefore be cultivated in all regions of Brazil (DUARTE; PAULL, 2015). Although it is highly appreciated for its sensory and nutritional qualities, the industrial use of the fruit is still limited, since it is highly perishable and its production is restricted to the months from August to November (WU et al., 2013). In Brazil, approximately 2.6 thousand tons of the fruit were commercialized in 2016 (CONAB, 2016). The jaboticaba pulp is white and has a pleasant taste, being sweet and acid at the same time. It is nutritionally relevant due to its carbohydrate, iron, copper, manganese, potassium and vitamin A contents (INADA et al., 2015). The skin, which represents $50 \%$ of the fruit, is usually discarded, although it contains high levels of dietary fibre and phenolic compounds (LEITE-LEGATTI et al., 2012). Therefore the development of new products using alternative ingredients such as jaboticaba skin is important, which could contribute to a healthier diet for a wide range of the population, besides cooperating with a reduction in organic waste.

Elementary school children are aged from 6 to 10. The formation of dietary habits is established at this stage and is influenced by factors such as family eating habits and/or the habits of school friends (BRASIL, 2012a). In addition, food consumption by children in this age range generally includes foods with high sugar, sodium and fat levels and low intakes of fruits and vegetables. This type of diet can be related to increasing risks for the develpment of chronic diseases such as vascular conditions and obesity (BARBALHO et al., 2016). Thus the school could be an appropriate place for the development of educational activities aiming at the improvement of eating habits, for example, encouraging the consumption of healthier and more nutritional products, which, in turn, could bring benefits in the upcoming phases of growth and development.

Muffins are baked products which are highly appreciated and consumed worldwide by large sectors of the population, including children. In Brazil, the market for baked goods showed a growth of $2.7 \%$ in 2015, giving a profit of $\mathrm{R} \$ 84.7$ billion (ABIP, 2015), and in the same year, sales of industrialized cakes reached 37.3 thousand tons (ABIMAP, 2015). The high acceptance of muffins is due mainly to their pleasant sweet flavour and soft texture, but other factors such as easy access, wide variety, low cost, easy consumption and a long shelf-life favour their production (MATOS et al., 2014). Despite this, in general muffins present low fibre levels (1.4 g.100 g-1) (USDA, 2016), which makes them products with high technological potential for the addition of new ingredients. Thus the objective of this work was to evaluate the sensory acceptance by children of muffins containing different levels of jaboticaba skin flour (JSF), and also determine the physicochemical composition of the traditional product and of that with the highest level of JSF with acceptance similar to that of the traditional muffins.

\section{Material and methods}

The ingredients were acquired in supermarkets in the town of Guarapuava, Paraná, Southern Brazil. The jaboticaba used had a deep dark red colour with a firm aspect, smooth skin, no flaws and medium size.

For the production of the skin flour, the fruits $(25 \mathrm{~kg})$ were washed with potable water, sanitized (1 litre of water 
per $10 \mathrm{~mL}$ of sanitizer for 20 minutes), and then washed a second time with potable running water. The skins, weighing $11.69 \mathrm{~kg}$, were removed manually to separate them from the pulp, placed on sifter-type trays $(42 \times 60 \mathrm{~cm})$ and dried in a drying chamber (Pardal ${ }^{\circledR}$, Brazil) at $65^{\circ} \mathrm{C}$ with air circulation for 36 hours. After dehydration, they were allowed to cool to room temperature $\left(22^{\circ} \mathrm{C}\right)$. The dry skins were ground in a domestic blender (Phillips Walita ${ }^{\circledR}$, Brazil) and passed through a $0.5 \mathrm{~mm} / 32$ mesh sieve $\left(\right.$ Bertel $^{\circledR}$, Brazil) to obtain the JSF $(1.74 \mathrm{~kg})$.

The different muffin formulations were prepared individually in the Dietary Technique Laboratory of the Nutrition Department at UNICENTRO, Brazil. Five formulations were prepared, each containing different levels of JSF: F1 standard (0\%), F2 (4.5\%), F3 (9\%), F4 (13.5\%) and F5 $(18 \%)$. These JSF levels were defined by the preliminary sensory tests carried out with the product. In addition to the JSF, the following ingredients were also used in the formulations: wheat flour (F1: 32.9\%, F2: $28.5 \%$, F3: 24\%, F4: $19.5 \%$ and F5: $15 \%$ ), crystal sugar (16.97\%), milk (15.63\%), chocolate chips (14.52\%), eggs (10.5\%), soybean oil $(7.15 \%)$, baking powder (1.34\%), vanilla sugar (1.12\%) and salt $(0.22 \%)$. The eggs, oil and milk were kneaded manually until a smooth dough was obtained, and then the wheat flour, crystal sugar, vanilla sugar, JSF, salt and baking powder were added and kneaded manually. Finally the chocolate chips were added to the dough. The muffins were placed in individual baking cups (diameter $3.9 \mathrm{~cm}$ and height $2.3 \mathrm{~cm}$ ) and baked in a preheated conventional oven (Consul ${ }^{\circledR}$, Brazil) at $180^{\circ} \mathrm{C}$ for approximately 21 minutes.

A group of 65 untrained tasters took part in the sensory analysis. They were children enrolled in a local elementary school in the town of Guarapuava, Paraná and were of both genders and aged from 7 to 10 . A classroom was allocated for the test and divided into booths. Each child was orientated by the adults responsible for the research during the sensory test, without interfering with the responses. The attributes evaluated were appearance, aroma, flavour, texture and colour using a 7-point structured facial hedonic scale, going from 1 for "very bad" to 7 for "very good". Overall acceptance and purchase intent were also evaluated with a 5-point structured scale, going from 1, which indicated "I really dislike it/would not buy it" to 5 , indicating "I really like it/would certainly buy it" (DUTCOSKY, 2013). Each child received a portion of the sample (aproximately $10 \mathrm{~g}$ ) in a white disposable plastic cup, marked with a three digit code, in a random, balanced and sequentially monadic way. A glass of water was served for the purpose of cleansing the palate during the sampling.

A multiple comparison test was applied to compare the muffin samples made in the laboratory with a similar product (traditional) widely commercialized in Brazil, without the addition of JSF (reference). For this test, the child indicated if the formulations prepared presented better, similar or worse flavours as compared to the reference product, using a 7-point hedonic scale, where 1 indicated "extremely worse than the first", and 7 indicated "extremely better than the first", adapted from Dutcosky (2013). The Acceptability Index (AI) was calculated according to the following Equation 1, where "A" is the average score obtained for the product; and "B" refers to the maximum score obtained for the product (DUTCOSKY, 2013).

$$
\text { Al }(\%)=\frac{A \times 100}{B}
$$

The following physicochemical analyses were carried out in triplicate on the JSF, the traditional formulation and on the experimental formulation with the highest level of JSF with sensory acceptance similar to that of the traditional formulation: Moisture: determined by drying to constant weight at $105^{\circ} \mathrm{C} \pm 2{ }^{\circ} \mathrm{C}$; Ash: incineration in a muffle furnace $\left(505^{\circ} \mathrm{C}\right)$; Lipid: hot extraction in a Soxhlet extractor with petroleum ether; Protein: determination of the total nitrogen content of the sample using the Kjeldahl method on a semi-micro scale (AOAC, 2011). The factor used for the conversion of nitrogen to protein was 6.25; Dietary fibre: determined using the calculus theory according to findings in the scientific literature (UNICAMP, 2011; SILVA et al., 2017); Carbohydrate: calculated by difference, using the triplicate results, according to Equation 2.

$\%$ Carbohydrates $=100-\left(\begin{array}{c}\% \text { moisture }+\% \text { protein }+ \\ \% \text { lipid }+\% \text { ash }+\% \text { dietary fibre }\end{array}\right)$

The total caloric value (kcal) was calculated theoretically using the following values: lipid $(8.37 \mathrm{kcal} / \mathrm{g})$, protein $(3.87 \mathrm{kcal} / \mathrm{g})$ and carbohydrate $(4.11 \mathrm{kcal} / \mathrm{g})$ (MERRILL; WATT, 1973). The Reference Daily Values (DV) were calculated in a theoretical manner in relation to $40 \mathrm{~g}$ of the sample, based on the mean recommended allowances for children aged 7 to 10 (DRI, 2005): $1.930 .49 \mathrm{kcal} / \mathrm{dia}$, $275.45 \mathrm{~g} /$ day of carbohydrate, $70.93 \mathrm{~g} /$ day of protein, $74.84 \mathrm{~g} /$ day of lipid and $13.72 \mathrm{~g} /$ day of dietary fibre.

All the data were analysed with the aid of the Statgraphics Plus ${ }^{\circledast}$, version 5.1 software using the analysis of variance (ANOVA), and the means compared using Tukey's test, the Student t-test and Dunnett's test, all evaluated with a $5 \%$ level of significance.

The study was approved by the Ethics in Research Committee of UNICENTRO, Brazil, under the case number of $608.950 / 2014$. The exclusion criteria were: allergy to any of the ingredientes used in the preparation of the muffins, not being a student in that particular school and not handing in the Informed Consent Form signed by the parent/guardian on time. 


\section{Results and discussion}

Table 1 shows the results of the sensory evaluation for the traditional muffin and those containing JSF. No significant differences $(p>0.05)$ were found between the samples for the attributes of appearance, aroma and colour. Similar results were verified by Bender et al. (2016) for colour and aroma on analyzing muffins with the addition of grape skin (5\%, $7.5 \%$ and $10 \%)$. Although the children found no differences for these attributes, the muffins containing JSF were darker in colour due to the large amount of anthocyanins present in the jaboticaba skin (732.77 mg.100 g $\mathrm{g}^{-1}$ ) (LEITE-LEGATTI et al., 2012). These pigments are responsible for the red, blue and purple colours of certain fruits and vegetables (CORTEZ et al., 2017), which can alter the colour and appearance of the products.

Higher scores were obtained for flavour and texture by samples $\mathrm{F} 1$ and $\mathrm{F} 2$ when compared to $\mathrm{F} 4$ and F5; and for F3 when compared to F5. Similar results were verified by Ferreira et al. (2012) when analysing the addition of JSF to cookies (0\%,5\% and $10 \%)$. In general, the addition of fruit byproducts containing high fibre contents can increase the firmness of the dough (WALKER et al., 2014), explaining the lower scores for texture (Table 1). This effect was verified in the present work, since the fibre is hygroscopic, promoting greater water retention in the products (WALKER et al., 2014). In addition, the high citric acid (9.4 g. $100 \mathrm{~g}^{-1}$ ) (LAMOUNIER et al., 2015) and phenolic compound (556.3 g GAE. kg ${ }^{-1}$ ) (LEITE-LEGATTI et al., 2012) contents found in the JSF result in the product acquiring acid and adstringent flavours, respectively (LESSCHAEVE; NOBLE, 2005). These characteritics could be responsible for the reduction in the scores for flavour of the muffins containing higher JSF levels.
An increasing tendency for post-baking brittleness was observed in formulations F4 and F5, which can be explained by the greater reduction in the wheat flour levels of these samples. Wheat flour, as opposed to the fruit skins, produces gluten, forming a viscoelastic web which lends greater elasticity and extensibilty to cake, bread and biscuit doughs (SHEWRY et al., 2002).

The tests for overall acceptance and purchase intent revealed higher scores for $\mathrm{F} 1$ and $\mathrm{F} 2$ as compared to F4 and F5. However, F1, F2 and F3 were equally accepted. These results show that the addition of up to $9 \%$ JSF to the muffins was well accepted by the tasters. Thus, with the exception of F5 (flavour), all the samples had an $\mathrm{Al} \geq 70 \%$, classifying them as showing good acceptability (TEIXEIRA et al., 1987). Such sensory results are positive and can favour the consumption of fibre amongst school age children, promoting healthier food consumption patterns. There is evidence indicating that the appropriate ingestion of fibre can reduce the risk of chronic diseases such as obesity and diabetes mellitus amongst children and adolescents (BRAUCHLA et al., 2012). Figure 1 shows the distribution of the tasters according to the hedonic scores awarded in the sensory test.

A higher percentage of scores above 5 (good) were obtained for the attributes, and of 4 (like) for overall acceptance. Scores below 5 were more frequent for formulations F4 and F5, especially for flavour and for colour. Figure 2 shows the mean results obtained in the multiple comparison test for the samples as compared to a commercialized muffin with no added JSF.

Sample F1 was considered to be the muffin with the best flavour as compared to the reference product, the remaining samples not presenting any significant difference $(p>0.05)$ as compared to the commercialized

Table 1. Sensory scores (mean \pm standard error) obtained for the muffins with addition of jaboticaba skin flour.

\begin{tabular}{|c|c|c|c|c|c|}
\hline \multirow{2}{*}{ Attributes } & \multicolumn{5}{|c|}{ Addition of jaboticaba skin flour } \\
\hline & $0 \%$ & $4.5 \%$ & $9 \%$ & $13.5 \%$ & $18 \%$ \\
\hline Appearance & $5.23 \pm 0.16^{a}$ & $5.36 \pm 0.14^{a}$ & $5.45 \pm 0.14^{a}$ & $5.25 \pm 0.18^{a}$ & $5.30 \pm 0.07^{a}$ \\
\hline $\mathrm{Al}(\%)$ & 74.71 & 76.57 & 77.86 & 75.00 & 75.71 \\
\hline Aroma & $5.28 \pm 0.16^{a}$ & $5.42 \pm 0.15^{a}$ & $5.45 \pm 0.14^{a}$ & $5.37 \pm 0.14^{a}$ & $5.40 \pm 0.14^{a}$ \\
\hline $\mathrm{Al}(\%)$ & 75.43 & 77.43 & 77.86 & 76.71 & 77.14 \\
\hline Flavour & $5.95 \pm 0.14^{a}$ & $5.74 \pm 0.14^{\mathrm{a}}$ & $5.55 \pm 0.17^{\mathrm{ab}}$ & $4.95 \pm 0.20^{\mathrm{bc}}$ & $4.75 \pm 0.23^{c}$ \\
\hline $\mathrm{Al}(\%)$ & 85.00 & 82.00 & 79.29 & 70.71 & 67.86 \\
\hline Texture & $5.97 \pm 0.13^{a}$ & $5.95 \pm 0.12^{a}$ & $5.73 \pm 0.13^{\mathrm{ab}}$ & $5.30 \pm 0.17^{b c}$ & $5.12 \pm 0.15^{c}$ \\
\hline $\mathrm{Al}(\%)$ & 85.29 & 85.00 & 81.86 & 75.71 & 73.14 \\
\hline Colour & $5.17 \pm 0.16^{a}$ & $5.34 \pm 0.15^{a}$ & $5.17 \pm 0.15^{a}$ & $5.31 \pm 0.17^{a}$ & $5.14 \pm 0.17^{a}$ \\
\hline $\mathrm{Al}(\%)$ & 73.86 & 76.29 & 73.86 & 75.86 & 73.43 \\
\hline Overall acceptance & $4.39 \pm 0.09^{a}$ & $4.37 \pm 0.09^{a}$ & $4.20 \pm 0.15^{\mathrm{ab}}$ & $3.83 \pm 0.14^{b}$ & $3.74 \pm 0.15^{b}$ \\
\hline $\mathrm{Al}(\%)$ & 87.80 & 87.40 & 84.00 & 76.60 & 74.80 \\
\hline Purchase intent & $4.35 \pm 0.12^{a}$ & $4.45 \pm 0.09 \mathrm{a}$ & $4.11 \pm 0.14^{\mathrm{ab}}$ & $3.72 \pm 0.16^{b}$ & $3.58 \pm 0.17^{b}$ \\
\hline
\end{tabular}

Different letters in the same line indicate significant difference according to Tukey's test $(p<0.05)$; Al: Acceptability Index. 

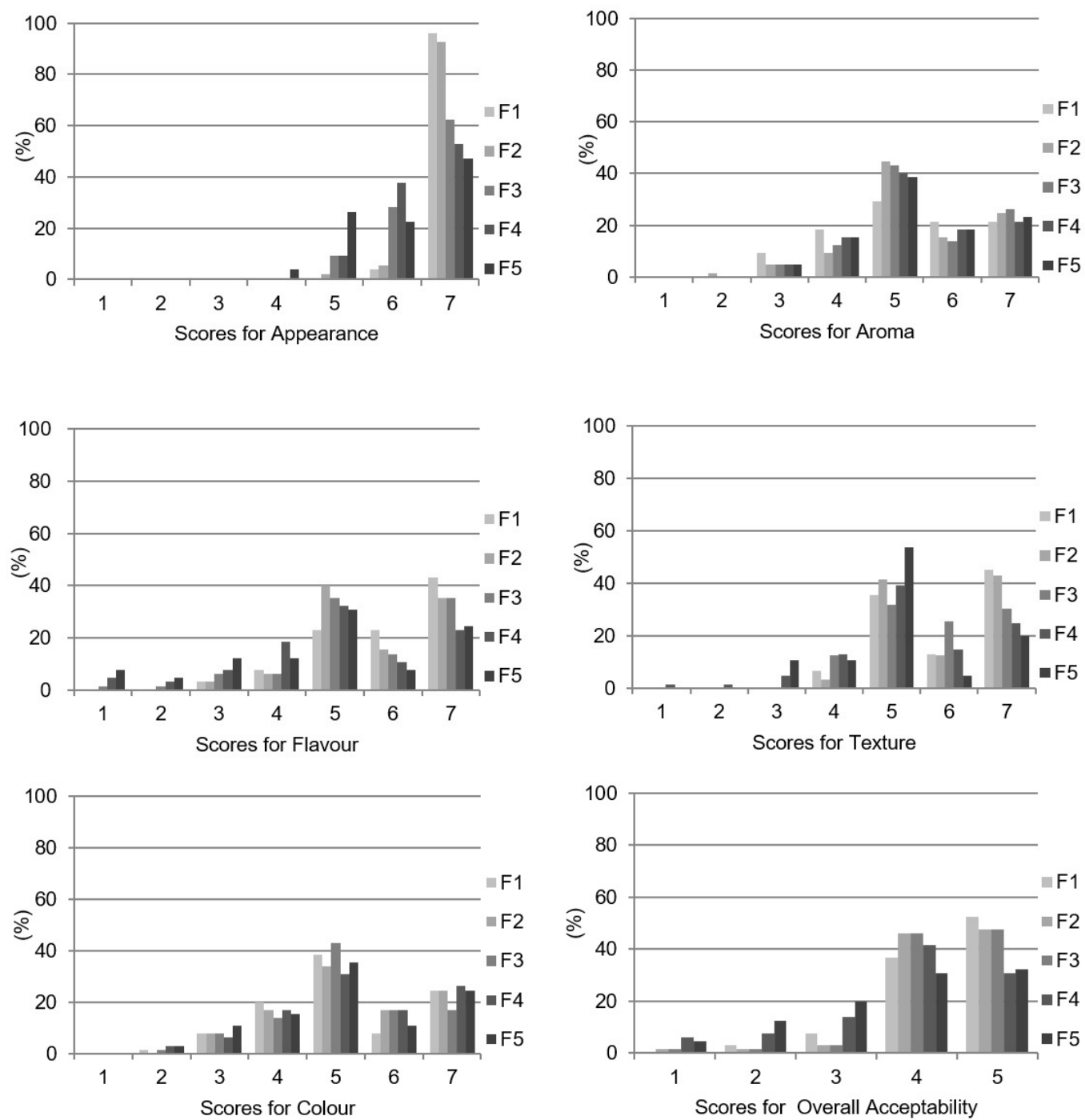

Figure 1. Distribution of the tasters according to the hedonic scores obtained for the attributes of appearance, aroma, flavour, texture, colour and overall acceptance of the traditional muffin and of those with the addition of $4.5 \%, 9 \%, 13.5 \%$ and $18 \%$ of jaboticaba skin flour.

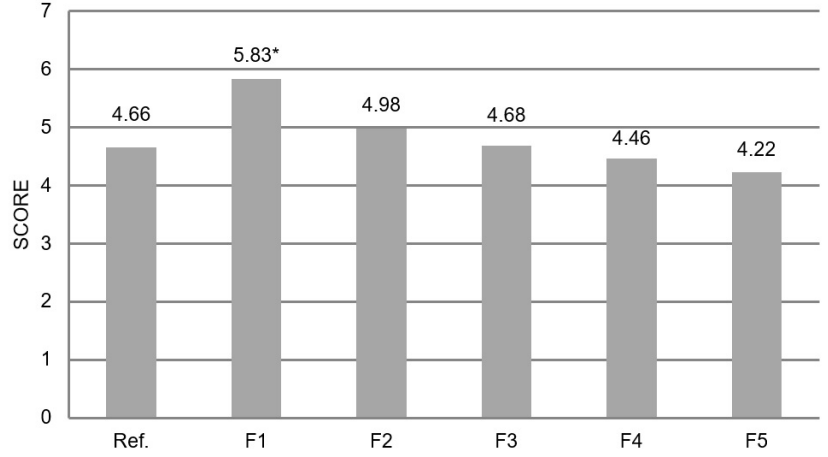

Figure 2. Means obtained in the multiple comparison test for the traditional muffin and for those containing $4.5 \%, 9 \%, 13.5 \%$ and $18 \%$ of jaboticaba skin flour, as compared to a commercialized muffin (reference), in relation to flavour. Obs.: *significant difference as compared to the reference product (Dunnett's test, $p<0.05$ ). brand. Thus the viability of commercializing muffins with the addition of up to $18 \%$ JSF for children was established. This could contribute to the production of healthier and more nutritionally valuable products (FERREIRA et al., 2015). It could also be effective in reducing the impact caused on the environment by the improper disposal of industrial waste.

Attributes such as aroma and flavour have a fundamental role in developing eating preferences, since these sensations are established and acquired since early childhood (DOTY, 2003). Thus sample F3 (9\% JSF) was selected for comparative purposes since it was the one with the highest level of JSF with acceptability similar to that of the traditional muffin (F1 - no added JSF) for those two characteristics in particular (Table 1). 
The addition of jaboticaba skin flour to muffins alters the physicochemical composition and their sensory acceptability by children Micheletti, J. et al.

Table 2. The physicochemical composition (mean \pm standard deviation) of the jaboticaba skin flour (JSF), the traditional muffin and the one with the addition of $9 \%$ JSF, and the Reference Daily Values (DV)*

\begin{tabular}{|c|c|c|c|c|c|}
\hline Parameters & JSF & $0 \%$ JSF & DV $(\%)^{*}$ & $9 \%$ JSF & DV $(\%)^{*}$ \\
\hline Moisture (\%) & $4.67 \pm 0.06$ & $17.67 \pm 0.05^{b}$ & ND & $19.97 \pm 0.06^{a}$ & NA \\
\hline Ash $\left(\mathrm{g} .100 \mathrm{~g} \mathrm{~g}^{-1}\right)$ & $2.21 \pm 0.04$ & $1.43 \pm 0.03^{b}$ & ND & $1.54 \pm 0.03^{\mathrm{a}}$ & NA \\
\hline Protein $\left(\mathrm{g} .100 \mathrm{~g}^{-1}\right)$ & $2.88 \pm 0.08$ & $6.97 \pm 0.03^{a}$ & 3.93 & $4.89 \pm 0.08^{b}$ & 2.76 \\
\hline Lipid $\left(\mathrm{g} .100 \mathrm{~g}^{-1}\right)$ & $0.20 \pm 0.07$ & $3.46 \pm 0.07^{a}$ & 1.85 & $3.28 \pm 0.04^{b}$ & 1.75 \\
\hline Carbohydrate $\left(\mathrm{g} .100 \mathrm{~g}^{-1}\right)$ & $90.04 \pm 0.25$ & $70.47 \pm 0.45^{a}$ & 10.23 & $70.31 \pm 0.72^{a}$ & 10.21 \\
\hline Calories (kcal.100 g-1) & $382.88 \pm 0.98$ & $345.55 \pm 1.65^{\mathrm{a}}$ & 7.16 & $335.38 \pm 1.12^{a}$ & 6.95 \\
\hline Dietary fibre $\left(\mathrm{g} .100 \mathrm{~g}^{1}\right)$ & $33.86 \pm 1.38^{\star \star}$ & $1.47^{\star * \star}$ & 4.29 & $4.31^{* \star *}$ & 12.56 \\
\hline
\end{tabular}

Different letters in the same line indicate significant difference according to the Student t-test $(p<0.05)$; *DV: nutrients evaluated from the mean of the DRI (2005), based on a diet of 1,930.49 kcal/day; mean portion of 40 grams (1 unit); Values calculated on a wet weight basis; ${ }^{*}$ Silva et al. (2017); ***Theoretical calculus (UNICAMP, 2011; SILVA et al., 2017); NA: not available.

Table 2 shows the physicochemical composition of the JSF, the traditional muffin and the one with the addition of 9\% JSF. On analysing JSF, Garcia et al. (2016) found lower values for ash $\left(1.40 \mathrm{~g} .100 \mathrm{~g}^{-1}\right)$, protein $\left(1.50 \mathrm{~g} .100 \mathrm{~g}^{-1}\right)$ and

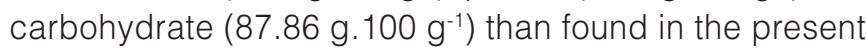
study, but higher values for moisture (7.86 g.100 g-1) and lipid $\left(1.43 \mathrm{~g} .100 \mathrm{~g}^{-1}\right)$. The diferences found in the compositions of flours can be explained by factors such as the crop, harvest and post-harvest conditions, and also by the technique used in food processing. The moisture content of the JSF conformed to the Brazilian legislation, since the maximum level established for flours by RDC n 263 (BRASIL, 2005) is $15 \%$. The JSF can be classified as an ingredient with a high fibre level ( $\geq 6 \%$ ) according to Resolution RDC $n^{\circ} 54$, of November 12 2012 (BRASIL, 2012b). The high ash level in the JSF can be characterized by the presence of minerals such as potassium (1.006.9 mg.100 $\mathrm{g}^{-1}$ ), calcium (510 mg. $100 \mathrm{~g}^{-1}$ ) and phosphorus (8 mg. $100 \mathrm{~g}^{-1}$ ) (INADA et al., 2015). These results demonstrate the feasibility of using vegetable waste for the elaboration of new baked goods with a better nutritional profile.

Greater moisture contents $(p<0.05)$ were found in F3 when compared to F1, a factor related to the increased water holding capacity of the fibre originating from the JSF that was added to the formulation (WALKER et al., 2014). Sample F3 showed higher levels of ash and lower levels of lipid and protein than F1, since wheat flour has lower mineral contents and higher protein and lipid

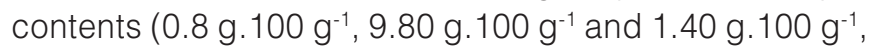
respectively) (UNICAMP, 2011), as compared to JSF. The fibre content of the formulation containing 9\% JSF (F3) showed a significant increase of $193 \%$ in relation to F1. This effect was due to the high fibre content found in the JSF (33.86 g.100 g-1) (SILVA et al., 2017), much higher than that found in wheat flour $\left(2.3{\mathrm{~g} .100 ~ \mathrm{~g}^{-1}}^{-1}\right.$ (UNICAMP, 2011). Thus the F3 sample can be considered a source of dietary fibre, since it has a minimum fibre content of 3\% (BRASIL, 2012b).

\section{Conclusions}

A level of addition of up to $9 \%$ of jaboticaba skin flour in muffins was well accepted by the children who took part in the sensory analysis, obtaining similar sensory acceptance to the traditional product. Futhermore, there was an increase in the levels of moisture, ash and fibre, and a reduction in the levels of protein and lipid in the products. Therefore jaboticaba skin flour can be considered a potential ingredient for addition to muffins and similar baked goods, with the possibility of being offered to children and presenting good perspectives for commercialization.

\section{References}

AL-SAYED, H. M.A.; AHMED, A. R. Utilization of watermelon rinds and sharlyn melon peels as a natural source of dietary fiber and antioxidants in cake. Annals of Agricultural Science, v. 58, n. 1, p. 83-95, 2013. http://dx.doi.org/10.1016/j.aoas.2013.01.012. ASSOCIAÇÃO BRASILEIRA DA INDÚSTRIA DE PANIFICAÇÃO E CONFEITARIA - ABIP. Desempenho do setor de panificação e confeitaria brasileiro. Brasilia, 2015. Available at: <http://www. abip.org.br/site/sobre-o-setor>. Accessed on: 3 june 2017.

ASSOCIAÇÃO BRASILEIRA DE BISCOITOS MASSAS ALIMENTÍCIA, PÃES E BOLOS INDUSTRIALIZADOS - ABIMAP. Estatística: bolo industrializado. São Paulo, 2015. Available at: <http://www. abimapi.com.br/estatistica-bolo-industrializado.php>. Accessed on: 2 june 2017.

ASSOCIATION OF OFFICIAL ANALYTICAL CHEMISTS - AOAC. Official methods of analysis of AOAC. 8th ed. Gaithersburg, 2011.

AYALA-ZAVALA, J. F.; VEGA-VEGA, V.; ROSAS-DOMÍNGUEZ, C.; PALAFOX-CARLOS, H.; VILLA-RODRIGUEZ, J. A.; SIDDIQUI, M. W.; DÁVILA-AVIÑA, J. E.; GONZÁLEZ-AGUILAR, G. A. Agroindustrial potential of exotic fruit byproducts as a source of food additives. Food Research International, v. 44, n. 7, p. 18661874, 2011. http://dx.doi.org/10.1016/j.foodres.2011.02.021. 
The addition of jaboticaba skin flour to muffins alters the physicochemical composition and their sensory acceptability by children Micheletti, J. et al.

BARBALHO, S. M.; FONTANA, L. C. S.; FINALLI, E. F. R.; MARTUCHI, K. A.; FERREIRA, M. C.; PAIVA FILHO, M. E.; CERRI, S. V. D. C.; SASAKI, V.; SPADA, A. P. M.; OSHIIWA, M.; SANTOS, M. C. B.; PESCININI-SALZEDAS, L. M.; BRAGANTE, L. S. Eating habits and presence of cardiovascular risks in children. International Journal of Adolescent Medicine and Health, v. 30, n. 2, p. 1-8, 2016. http://dx.doi.org/10.1515/ijamh-2016-0045. PMID: 27508956.

BENDER, A. B.; SPERONI, C. S.; SALVADOR, P. R.; LOUREIRO, B. B.; LOVATTO, N. M.; GOULART, F. R.; MIRANDA, M. Z.; SILVA, L. P.; PENNA, N. G. Grape pomace skins and the effects of its inclusion in the technological properties of muffins. Journal of Culinary Science \& Technology, v. 5, n. 1, p. 1-15, 2016.

BRASIL. Ministério da Saúde. Agência Nacional de Vigilância Sanitária. Resolução RDC n²63, de 22 de setembro de 2005. Aprova o "Regulamento Técnico para produtos de cereais, amidos, farinhas e farelos". Diário Oficial [da] República Federativa do Brasil, Brasília, DF, 2005. Seção 1.

BRASIL. Ministério da Educação. Manual de orientação para a alimentação escolar na educação infantil, ensino fundamental, ensino médio e na educação de jovens e adultos. 2. ed. Brasília: PNAE/CECANE- SC, 2012 a.

BRASIL. Ministério da Saúde. Agência Nacional de Vigilância Sanitária. Resolução RDC n 54, de 12 de novembro de 2012. Dispõe sobre o Regulamento Técnico sobre informação nutricional complementar. Diário Oficial [da] República Federativa do Brasil, Brasília, DF, 2012b. Seção 1.

BRAUCHLA, M.; JUAN, W.; STORY, J.; KRANZ, S. Sources of dietary fiber and the association of fiber intake with childhood obesity risk (in 2-18 year olds) and diabetes risk of adolescents 12-18 year olds: NHANES 2003-2006. Journal of Nutrition and Metabolism, v. 2012, p. 1-7, 2012. http://dx.doi.org/10.1155/2012/736258. PMid:22957219.

COMPANHIA NACIONAL DE ABASTECIMENTO - CONAB. Custos de produção. Brasília, 2016. Available at: <http://dw.prohort. conab.gov.br/pentaho/Prohor>. Accessed on: 29 may 2017.

CORTEZ, R.; LUNA-VITAL, D. A.; MARGULIS, D.; GONZALEZ DE MEJIA, E. Natural pigments: stabilization methods of anthocyanins for food applications. Comprehensive Reviews in Food Science and Food Safety, v. 16, n. 1, p. 180-198, 2017. http://dx.doi. org/10.1111/1541-4337.12244.

DIETARY REFERENCE INTAKES - DRI. Dietary reference intakes for energy, carbohydrate, fiber, fat, fatty acids, cholesterol, protein and amino acids. Washington: National Academy Press, 2005.

DOTY, R. L. Handbook of olfaction and gustation. 2nd ed. New York: Marcel Dekker, 2003. http://dx.doi.org/10.1201/9780203911457.

DUARTE, O.; PAULL, R. Exotic fruits and nuts of the New World. Oxfordshire: CABI, 2015. http://dx.doi.org/10.1079/97 81780645056.0000 .
DUTCOSKY, S. D. Análise sensorial de alimentos. 4. ed. Curitiba: Champagnat, 2013.

ESHAK, N. S. Sensory evaluation and nutritional value of balady flat bread supplemented with banana peels as a natural source of dietary fiber. Annals of Agricultural Science, v. 61, n. 2, p. 229-235, 2016. http://dx.doi.org/10.1016/j.aoas.2016.07.002.

FERREIRA, A. E.; FERREIRA, B. S.; LAGES, B.; MARIA, M.; RODRIGUES, F. Produção, caracterização e utilização da farinha de casca de jabuticaba em biscoitos tipo cookie. Alimentos e Nutrição, v. 23, n. 4, p. 603-607, 2012.

FERREIRA, M. S.; SANTOS, M. C.; MORO, T. M.; BASTO, G. J.; ANDRADE, R. M.; GONÇALVES, É. C. Formulation and characterization of functional foods based on fruit and vegetable residue flour. Journal of Food Science and Technology, v. 52, n. 2, p. 822-830, 2015. http://dx.doi.org/10.1007/s13197-0131061-4. PMid:25694690.

GALANAKIS, C. M. Innovation strategies in the food industry: tools for implementation. Amsterdam: Elsevier Academic Press, 2016.

GARCIA, L. G. C.; SILVA, A. H. S.; CUNHA, P. C.; DAMIANI, C. Preparation of gluten-free noodles incorporated of jabuticaba peel flour. Journal of Food and Nutrition Research, v. 4, n. 2 , p. 82-87, 2016.

GUSTAVSSON, J.; CEDERBERG, C.; SONESSON, U.; VAN OTTERDIJK, R.; MEYBECK, A. Global food losses and food waste. Roma: Food and Agriculture Organization of the United Nations, 2011.

INADA, K. O. P.; OLIVEIRA, A. A.; REVORÊDO, T. B.; MARTINS, A. B. N.; LACERDA, E. C. Q.; FREIRE, A. S.; BRAZ, B. F.; SANTELLI, R. E.; TORRES, A. G.; PERRONE, D.; MONTEIRO, M. C. Screening of the chemical composition and occurring antioxidants in jabuticaba (Myrciaria jaboticaba) and jussara (Euterpe edulis) fruits and their fractions. Journal of Functional Foods, v. 17, n. 1, p. 422-433, 2015. http://dx.doi.org/10.1016/j.jff.2015.06.002.

LAMOUNIER, M. L.; ANDRADE, F. C.; MENDONÇA, C. D.; MAGALHÃES, M. L. Desenvolvimento e caracterização de diferentes formulações de sorvetes enriquecidos com farinha da casca da jabuticaba (Myrciaria cauliflora). Revista do Instituto de Latícinios Cândido Tostes, v. 70, n. 2, p. 93-104, 2015. http:// dx.doi.org/10.14295/2238-6416.v70i2.400.

LEITE-LEGATTI, A. V.; BATISTA, Â. G.; DRAGANO, N. R. V.; MARQUES, A. C.; MALTA, L. G.; RICCIO, M. F.; CARVALHO, J. E. Jaboticaba peel: antioxidant compounds, antiproliferative and antimutagenic activities. Food Research International, v. 49, n. 1, p. 596-603, 2012.

LESSCHAEVE, I.; NOBLE, A. C. Polyphenols: factors influencing their sensory properties and their effects on food and beverage preferences. The American Journal of Clinical Nutrition, v. 81, n. 1, p. 330S-335S, 2005. Supplement. http://dx.doi.org/10.1093/ ajcn/81.1.330S. PMid:15640499. 
The addition of jaboticaba skin flour to muffins alters the physicochemical composition and their sensory acceptability by children Micheletti, J. et al.

MATOS, M. E.; SANZ, T.; ROSELL, C. M. Establishing the function of proteins on the rheological and quality properties of rice based gluten free muffins. Food Hydrocolloids, v. 35, n. 1, p. 150-158, 2014.

MERRILL, A. L.; WATT, B. K. Energy values of foods: basis and derivation. Washington: USDA, 1973. (Agricultural Handbook, ก. 74).

SHEWRY, P. R.; HALFORD, N. G.; BELTON, P. S.; TATHAM, A. S. The structure and properties of gluten: an elastic protein from wheat grain. Philosophical Transactions of the Royal Society of London. Series B, Biological Sciences, v. 357, n. 1418, p. 133-142, 2002. http://dx.doi.org/10.1098/rstb.2001.1024. PMid:11911770.

SILVA, J. K.; BATISTA, Â. G.; CAZARIN, C. B. B.; DIONÍSIO, A. P.; BRITO, E. S.; MARQUES, A. T. B.; MARÓSTICA JUNIOR, M. R. Functional tea from a Brazilian berry: Overview of the bioactives compounds. Lebensmittel-Wissenschaft + Technologie, v. 76, n. 1, p. 292-298, 2017. http://dx.doi.org/10.1016/j.Iwt.2016.06.016. TEIXEIRA, E.; MEINERT, E. M.; BARBETTA, P. Análise sensorial de alimentos. Florianópolis: UFSC, 1987.
UNITED STATES DEPARTMENT OF AGRICULTURE - USDA. National nutrient database for standard reference release 28. Beltsville: National Agricultural Library, 2016. Available at: <www.usda.gov>. Accessed on: 15 june 2017.

UNIVERSIDADE ESTADUAL DE CAMPINAS - UNICAMP. Tabela brasileira de composição dos alimentos - TACO. 4. ed. Campinas: UNICAMP; NEPA, 2011.

WALKER, R.; TSENG, A.; CAVENDER, G.; ROSS, A.; ZHAO, Y. Physicochemical, nutritional, and sensory qualities of wine grape pomace fortified baked goods. Journal of Food Science, v. 79, n. 9, p. S1811-S1822, 2014. http://dx.doi.org/10.1111/17503841.12554. PMid:25102950.

WU, S. B.; LONG, C.; KENNELLY, E. J. Phytochemistry and health benefits of jaboticaba, an emerging fruit crop from Brazil. Food Research International, v. 54, n. 1, p. 148-159, 2013. http:// dx.doi.org/10.1016/j.foodres.2013.06.021.

ZAGO, M. F. C.; CALIARI, M.; SOARES JÚNIOR, M. S.; CAMPOS, M. R. H.; BATISTA, J. E. R. Jabuticaba peel in the production of cookies for school food: technological and sensory aspects. Ciência e Agrotecnologia, v. 39, n. 6, p. 624-633, 2015. http:// dx.doi.org/10.1590/S1413-70542015000600009. 